\title{
Effect of cold-water irrigation on bacterial wilt pathogen of tomato.
}

\begin{abstract}
Bacterial wilt caused by Ralstonia solanacearum is one of the most devastating bacterial diseases of plants worldwide. Management of bacterial wilt in tomato and other crops has been difficult, and so novel but easily implemented control methods are being sought. To evaluate the effect of cold-water irrigation on bacterial wilt of tomato, four treatments were used in which CF (chemically fertilized) soil and CF + FYM (chemical fertilizer + farmyard manure $[F Y M]$ ) soil were inoculated with a bacterial suspension (R. solanacearum strain YU1Rif43) at 106 colony forming units (CFU) g-1 soil. Tomato seedlings were grown in Agri-pots in a plant growth chamber. The soil was irrigated with water that was kept at the same temperature in each treatment: $4,10,20$, or $30^{\circ} \mathrm{C}$. Incidence and severity of wilt, counting of the colonies of the culturable population of pathogen, and dry-mass and height of the plants were examined. After 45 days and in both kinds of soil, most of the plants had wilted in soil irrigated at $30^{\circ} \mathrm{C}$. Wilt incidence was substantially reduced when transplanted seedlings were irrigated at lower temperatures $\left(4-20^{\circ} \mathrm{C}\right)$. Survival of R. solanacearum was also reduced after being irrigated with water at lower temperatures, indicating that the reduced incidence of wilt was linked to reduced survival of the pathogen. Dry-mass and plant height were slightly higher under control conditions than in soils irrigated at lower temperatures. This study suggests that cold-water irrigation could significantly reduce bacterial wilt of tomato and have an adverse effect on survival of the wilt pathogen.
\end{abstract}

Keyword: Incubation; Low temperature; Plant vigor; Ralstonia solanacearum; Survival. 